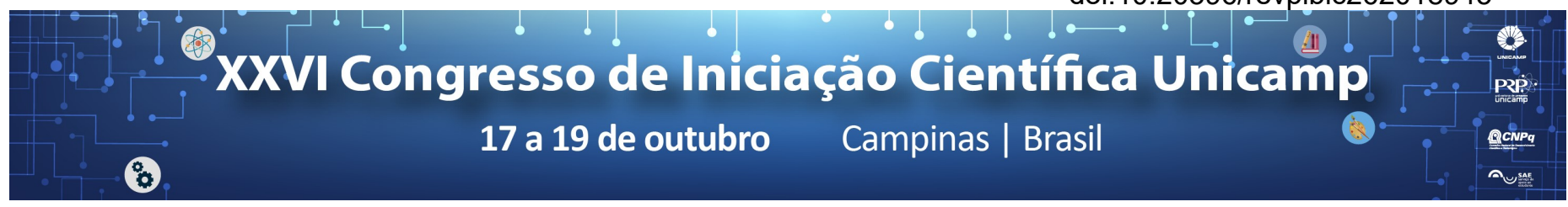

\title{
EXPERIÊNCIAS PRODUZIDAS NA FORMAÇÃO INICIAL DE PROFESSORES.
}

\author{
Maiara Ariele Pedersen*, Ana Maria Falcão de Aragão.
}

\section{Resumo}

Em uma disciplina oferecida aos estudantes do primeiro semestre de 2015 do curso de Pedagogia, tiveram como objetivo contribuir para que os futuros professores pudessem se apropriar do seu lugar de docente desde a entrada na Universidade e, depois, na escola, reconhecessem expectativas e necessidades de quem inicia uma relação profissional nesse contexto. Foi sugerido aos 49 estudantes que fizessem, individualmente, registros poéticos de cada uma das aulas: relatos da aula anterior que expressassem, além da síntese, a essência do que foi vivido, usando recursos expressivos verbais ou não verbais. O presente projeto de iniciação científica tem como objetivo analisar os registros poéticos produzidos pelos estudantes do sexto semestre de um curso de Pedagogia, buscando apontar quais e se as experiências consideradas formativas estão presentes nos textos dos alunos culminando na apreensão sensível da realidade, que possibilita a mudança, o questionamento ou a reflexão. Para satisfazer a esse objetivo, os estudantes que participaram da disciplina em 2015 serão convidados a constituir um novo grupo em uma disciplina eletiva ministrada pela mesma professora com o objetivo de analisarem o que foi produzido naquele primeiro semestre de 2015 e quais foram as experiências consideradas formativas por eles.

Palavras-chave: Experiência; Registros Poéticos; Formação Inicial de Professores.

\section{Introdução}

Neste projeto de iniciação científica, me propus a analisar os registros poéticos produzidos pelos estudantes do sexto semestre de um curso de Pedagogia, buscando apontar quais e se os princípios da promoção da reflexividade estão presentes nos textos dos alunos. Para satisfazer a esse objetivo, os 49 estudantes que participaram da disciplina EP 107 em 2015 foram convidados a constituir um novo grupo em uma disciplina eletiva em 2017 com o objetivo de analisarem $o$ que foi produzido naquele primeiro semestre de 2015 e a produção de novos registros poéticos buscando apontar quais foram as experiências consideradas formativas por eles.

\section{Resultados e Discussão}

Embora fosse interessante, não seria viável nesta pesquisa de Iniciação Científica a análise individual de todos os registros produzidos. Fez-se, então, necessário que se estabelecesse um recorte para análise. No final da disciplina, como uma última atividade, foi proposto pela professora às alunas a elaboração de um registro poético em forma de carta endereçada a ela e a seu PED. Em suma, o que se esperava era responder às perguntas: $O$ que ficou? $O$ que restou depois de tudo que vivemos juntos? O que levo de aprendizado, mobilização, transformação? Quais foram as experiências formativas?

O fio condutor da análise sobre os registros poéticos que foram apresentados em forma de carta, foi um critério coerente para selecionar o que há de mais expressivo, reservando os demais registros para consulta e complementação da análise. Levando em consideração esse recorte, me dedicarei com mais ênfase em um total de 23 produções.

Os registros poéticos pré-selecionados pelo recorte adotado, foram analisadas sob a luz do Paradigma Indiciário e da proposta dos Núcleos de Significação, o que permitiu indiciar um conjunto de saberes reveladores de importantes dimensões do desenvolvimento pessoal e da formação docente. A análise se deu, inicialmente, a partir de uma leitura flutuante de todos os registros, ou seja, todas as cartas.

Ao final da análise, foram compostos 4 núcleos de significação. Apresentarei um a um, trazendo trechos de registros articulados a reflexões teóricas e propostas interpretativas. Os Núcleos são os seguintes:

- Foi como estar de volta a terrenos conhecidos;

- Com espaço para falar, as interações se efetivam;

- A memória é viva e a gente sempre a ressignifica;

- O que ficou...

É interessante notar que a proposta de uma nova disciplina mobilizou sentimentos nas alunas, e que a vontade de ter aquele espaço/tempo vivido em 2015 pudesse de alguma maneira ser (re)vivido. Em seu registro, as palavras da aluna chamam a atenção para a dimensão da atmosfera que foi criada em 2015 e por ter sido a luzinha que piscava no meio de tantas aulas, de tantas mudanças e adaptações a expectativa desta nova disciplina, que propunha retomar a disciplina anterior, era bem grande.

A sala 2015 do integral, a professora Ana e seu fiel companheiro das aulas Raul. Uma das primeiras disciplinas (EP 107) da Pedagogia que tinha um pouquinho de amor, de troca, de experiências, de leituras. Semelhante a uma luzinha que piscava no meio de tantas aulas, de tantas mudanças e adaptações. (Isabela Antonelli, 22/09/2017)

\section{Conclusões}

Experiência foi viver uma situação profundamente, deixando-se permear por ela. Para os estudantes também significou processo marcante da vida humana, acontecimento profundo que caracteriza nossa existência singular e de toda a humanidade, sincronicamente. 